\title{
Species Composition of a Degraded Watershed in Amawbia, Anambra State, Nigeria
}

\author{
Ukpaka Chukwujekwu Gratius ${ }^{1}$, Nnabude Peter Chinedu ${ }^{2, *}$ \\ ${ }^{1}$ Biological Science Department, Faculty of Natural Sciences, Chukwuemeka Odumegwu Ojukwu University, Uli, Nigeria \\ ${ }^{2}$ Department of Soil Science, Faculty of Biological Sciences, Nnamdi Azikiwe University, Awka, Nigeria
}

Email address:

ukpakachukwujekwu@yahoo.com (U. C. Gratius),nnabudepc@yahoo.com (N. P. Chinedu)

${ }^{*}$ Corresponding author

\section{To cite this article:}

Ukpaka Chukwujekwu Gratius, Nnabude Peter Chinedu. Species Composition of a Degraded Watershed in Amawbia, Anambra State, Nigeria. American Journal of Plant Biology. Vol. 3, No. 1, 2018, pp. 1-7. doi: 10.11648/j.ajpb.20180301.11

Received: September 20, 2017; Accepted: October 11, 2017; Published: January 30, 2018

\begin{abstract}
This work was carried out in a period that spans the rainy and dry seasons of 2010 - 2011. In times past, Anambra State was rich in chains of productive watershed, saturated with luxuriant plant species. This however is now history owing to steadily increasing, degradatory anthropogenic influences. Ignorance and crass indifference on the indispensability of plant resources to man's survival in tropical Africa has also resulted in very poor biodiversity of our watersheds. Amawbia watershed is not an exception. With the assistance of a field taxonomist and relevant texts, tree, climber, shrub, grass and forb species were firstly identified and recorded for sampled sites (sites A - E). Unlike productive watersheds, the dominant species encountered in this watershed were grasses and forbs. Dominant individual plants include: Heivea brasiliensis, Senna siamea, Napoleana imperialis, Dactyledenia barteri, Pentaclethra macrophyla, (Trees); Gongronema latifolium, Dioscorea dumentorum, Telfeiria occidentalis, Smilax anceps, Cissus aralioides (Climbers); Olax viridis, Mimosa invisa, Bambusa vulgaris, Vernonia amygdalina, Sarcocephalum laxiflora (Shrubs); Zea mays, Panicum maxima, Imperata cylindrica, Sporobolus pyramidalis, Andropogon tectorum (Grass); Amaranthus viridis, Ageratum conyzoides, Sida acuta, Gomphrena celosoides, Ocimum basilicum (Forbs). Most of these species are not very important in terms of economic relevance.
\end{abstract}

Keywords: Specie Composition, Degraded, Watershed, Biodiversity, Anthropogenic Influences

\section{Introduction}

\subsection{Background of Study}

A watershed is an area of land that drains rain water or snow into one location such as a stream, lake or wetland. These water bodies supply our drinking water, water for agriculture and manufacturing, offer opportunities for recreation, and provide habitats to numerous plants and animals. Unfortunately, various forms of pollution, including run-off and erosion, can interfere with the health of the watershed. Therefore, it is important to protect the quality of our watersheds [10].

\subsection{Statement of the Problem}

Many people look upon the watersheds as natural dumping site for all manner of wastes. Others see them as the natural home for agricultural activities, and other commercial ventures. The integrity and sanctity of the watershed therefore, is not respected. Watershed protection, which is a means of protecting a lake, river, or stream by managing the entire watershed that drains into it, is an indispensable prerequisite for the sustainability of all human communities. Clean, healthy watersheds depend on an informed public to make the right decisions when it comes to the environment and actions carried on by its inhabitants. The earth is covered in $70 \%$ water and unfortunately $40-50 \%$ of our nations' waters are impaired or threatened. "Impaired" means that the water body does not support one or more of its intended uses. This could mean that the water is not suitable for drinking, swimming and fishing purposes. The leading causes of pollution in our waterways are sediments, bacteria (such as Escherichia coli) and excess nutrients. Sediments can suffocate fish by clogging their gills and the presence of bacteria alone can indicate that other viruses and germs can be found in the water as well. Erosion, runoff of animal waste and overflowing of combined sewers are just a few ways 
these pollutants reach our waters [10]. In parts of Southeast Nigeria, Anambra state for instance (emphasis ours), population explosion, rise in and unplanned industrial, infrastructural and agricultural development, together with other unacceptable environmental practices, have exacerbated watershed degradation. This has continuously impacted negatively on watershed sustainability (particularly water safety and biodiversity). As natural vegetation is rapidly being replaced with impervious surfaces (roof tops, concrete surfaces, paved roads etc), increased runoff and excessive flooding which results in siltation, leaching and erosion (recurring decimals in the South East) occur. The associated pollutants constitute health hazards to man and other living organisms which depend on the water and its resources for overall sustenance, growth and advancement.

Anambra State has a very large population of traders, artisans, land speculators, unemployed folks and even government workers, who have little or no regard for vegetation. This has led to dizzying (unbelievable) rates and acts of deforestation with its associated degradation. Considering all these factors and activities, the need arises therefore to ascertain the level of damage suffered by plant species in these watershed.

\subsection{Significance of the Problem}

The Amawbia watershed (under study) lies on a relatively higher incline than other neighbouring/surrounding watersheds in Awka, Nibo, Nise, Nawfia, Enugu Agidi, Enugwu-Ukwu et cetera. This was probably why the Anambra State Government selected this particular watershed to serve as her Agricultural Development Project (ADP) field site. This watershed is surrounded by hotels, diesel, fuel, gas and kerosene dispensing mega stations, a medium capacity prison, government offices, banks, residential buildings, paved and unpaved roads, industries, factories and other commercial enterprises. On the watershed proper, massive deforestation, continual cropping and harvesting on the same undulating land, fuel wood gathering, overharvesting of more useful species, bush-burning, yearly application of inorganic fertilizer, slash and burn agriculture and continuous flow of point and non-point sources of sewage/effluents from roads, cesspits, floodwaters and incinerators, gaseous effluents, et cetera, introduce hazardous, disease-causing materials into the water and atmosphere. These are also filtered by surrounding vegetation, thus rendering the fish, fruit, vegetables, leaves, tubers, and other medicinal products harvested from the site neither palatable nor safe for consumption by man or his livestock. These deleterious materials are also naturally distributed through the water channels to the numerous other watersheds downstream in neighbouring communities, thereby ensuring a vicious cycle of toxic substances distribution all over the State, through food chains and food webs. [5] observes that the ever-increasing speed of infrastructural development has resulted in many environmental problems. These include deforestation, siltation of streams, eutrophication (contribution ours), water pollution and invariably, water scarcity. Thus the decline of forests and freshwater and concomitant agricultural activities lead to land use and land cover changes, hence the degradation of the watershed system. Also, infrastructural developments are more often than not associated with the excavation of sand and gravel. These are largely confined to the beds of streams and rivers and their banks and are largely indispensable in many construction projects. Consequently, settlement encroachments close to the streams and deforestation have contributed to seasonal shortages of water. The swamp, fresh watershed and spring areas have been used for building residential houses, private schools, animal pens, Saw mills et cetera. Sometimes, dams are built without involving the rural community in the decision [5].

\subsection{Purpose of the Study}

This work will go a long way in helping to enlighten people, especially in developing nations, of the concept of watershed, its usefulness in terms of organic (plants for example) and inorganic resources (water and sand for example), their relationship to forests and tourism development; why they are being degraded, what is degrading them, how to arrest/avert further degradation, and finally, what the future portends for mankind if and when, especially tropical watersheds, are wisely midwifed and judiciously developed.

The white races of the world having experienced more years of civilization, fully acknowledge the wisdom inherent in wise stewardship of the earth, and its finite resources. Unfortunately, they inhabit mostly temperate regions of the world. This work serves as a wakeup call, most especially to all the progressive forces of the world (environmentalists, intellectuals, leaders of thought, politicians, women and youth representatives), to pool their resources together and consciously set in motion, the long awaited vehicle of change towards a massive, all-encompassing campaign on environmental protection and habitat conservation. Watersheds are more than just drainage areas in and around our communities. They are necessary habitats for plants and animals, and provide drinking water for people and wildlife. They also provide the opportunities for recreation and enjoyment/appreciation of nature. Protection of the natural resources in our watershed is essential to maintain the health and wellbeing of all living things, both now and in the future [7].

\subsection{Scope of the Study}

This research work will be limited to the watershed traversing the Ministry of Agriculture, Amawbia (old government lodge), Awka South Local Government Area, Anambra State, Nigeria. Floristic studies will be focused on trees, climbers, shrubs, grasses and forbs in the watersheds.

\subsection{Objectives of the Study}

To identify the species composition of the watershed. 


\section{Literature Review}

\subsection{Definition}

Watersheds have traditionally designated the dividing line or drainage divide, between two drainage basins: that is, the ridge of high land or boundary separating regions that are drained by different river systems or bodies of water (lake, sea, etc). In some instances, watershed has come to be used interchangeably with the definition for drainage basin. In other words, "watershed" often refers to the entire region or area where all the waters drain into the same body of water, rather than just the elevation separating the waters flowing into different basins. Both are accepted definitions [8]. A drainage basin is a region of land where water from rain drains downhill into a body of water such as a river, lake, dam, estuary, wetland, sea or ocean. The drainage basin includes both the streams and rivers that convey the water, as well as the land surfaces from which water drains into those channels. The drainage basin acts like a funnel, collecting all the water within the area covered by the basin and channeling it into a waterway. Smaller watersheds are part of progressively larger watersheds. Each drainage basin is separated topographically from adjacent basins by a ridge, hill, or mountain, which is known as a water divide or a watershed. Water on one or the other side of that divide either flows toward or away from a particular basin [8]. Homes, farms, ranches, forests, small towns, big cities, and more can make up watersheds. Some watersheds cross county, state and international boundaries. Watersheds come in all shapes and sizes. Some are millions of square miles, while others are just a few acres. Just as creeks drains into rivers, watersheds are nearly always part of a larger watershed [2].

\subsection{Important Watershed Characteristics}

i. Drainage Area: The drainage area (A) is probably the single most important watershed characteristics for hydrologic design. It reflects the volume of water that can be generated from rainfall. It is common in hydrologic design to assume a constant depth of rainfall occurring uniformly over the watershed. Under this assumption, the volume of water available for runoff would be the product of rainfall depth and the drainage area [11].

ii. Watershed Length: This is the second watershed characteristic of interest. While the length increases as the drainage increases, the length of a watershed is important in hydrologic computations. Watershed length is usually defined as the distance measured along the main channel from the watershed outlet to the basin divide. Thus, the length is measured along the principal flow path. While the drainage area and length are both measures of watershed size, they may reflect different aspects of size. The drainage area is used to indicate the potential for rainfall to provide a volume of water. The length is usually used in computing a time parameter which is a measure of the travel time of water through a watershed [11].

iii. Watershed Slope: Flood magnitudes reflect the momentum of the runoff. Slope is an important factor in the momentum. Both watershed and channel slope may be of interest. Watershed slope reflects the rate of change of elevation with respect to distance along the principal flow path. Typically, the principal flow path is delineated, and the watershed slope(s) is computed as the difference in elevation $(\Delta \mathrm{E})$ between the end points of the principal flow path divided by the hydrologic length of the flow path (L): $\mathrm{S}=\Delta \mathrm{E} / \mathrm{L}$ [11].

iv. Watershed shape: Watersheds have an infinite variety of shapes, and the shape supposedly reflects the way that runoff will "bunch up" at the outlet. A circular watershed would result in runoff from various parts of the watershed reaching the outlet at the same time. An elliptical watershed having the outlet at one end of the major axis and having the same area as the circular watershed would cause the runoff to be spread out over time, thus producing a smaller flood peak than that of the circular watershed [11].

\section{Materials and Methods}

Trees, climbers, shrubs, grasses and forbs species (Growth Forms), were identified and recorded for each site $(A-E)$, with the assistance of a field taxonomist and relevant texts ([1], [3] and [9]).

\subsection{Description of the Study Area}

The study was carried out along a watershed in Amawbia, which traverses the Anambra State Agricultural Development Project Field location, Amawbia-Awka South Local Government Area, at five (5) different sites. These sites are as follows: Site A (forest site); Site B (short term fallow site); Site C (long term fallow site); Site D (current usage farming site (slope) and Site E (current usage flat farming site). Amawbia is $325 \mathrm{~m}$ above sea level and lies between latitudes $06^{\circ} 11.434^{\prime} \mathrm{N}-06^{\circ} 11.643 \mathrm{~N}$ and longitudes $07^{\circ} 03.649^{\prime} \mathrm{E}-$ $07^{\circ} 03.691^{\prime} \mathrm{E}$. It falls within the humid tropical climatic belt of Nigeria. There are two seasons which are well marked in this region where the maximum average rainfall is experienced during July and August. The mean annual rainfall is in the range of $1500-2500 \mathrm{~mm}$ [4]. Amawbia has a mean annual maximum temperature of $32.9^{\circ} \mathrm{C}$; mean annual minimum temperature of $23.4^{\circ} \mathrm{C}$, while the soil monthly mean temperature is $30^{\circ} \mathrm{C}$ [6].

\subsection{Sampling Procedure/Technique and Sample Collection}

The study carried out during the rainy and dry season of 2010/2012, at five (5) sampling locations, namely sites A - E, as shown in Figure 1 below. 


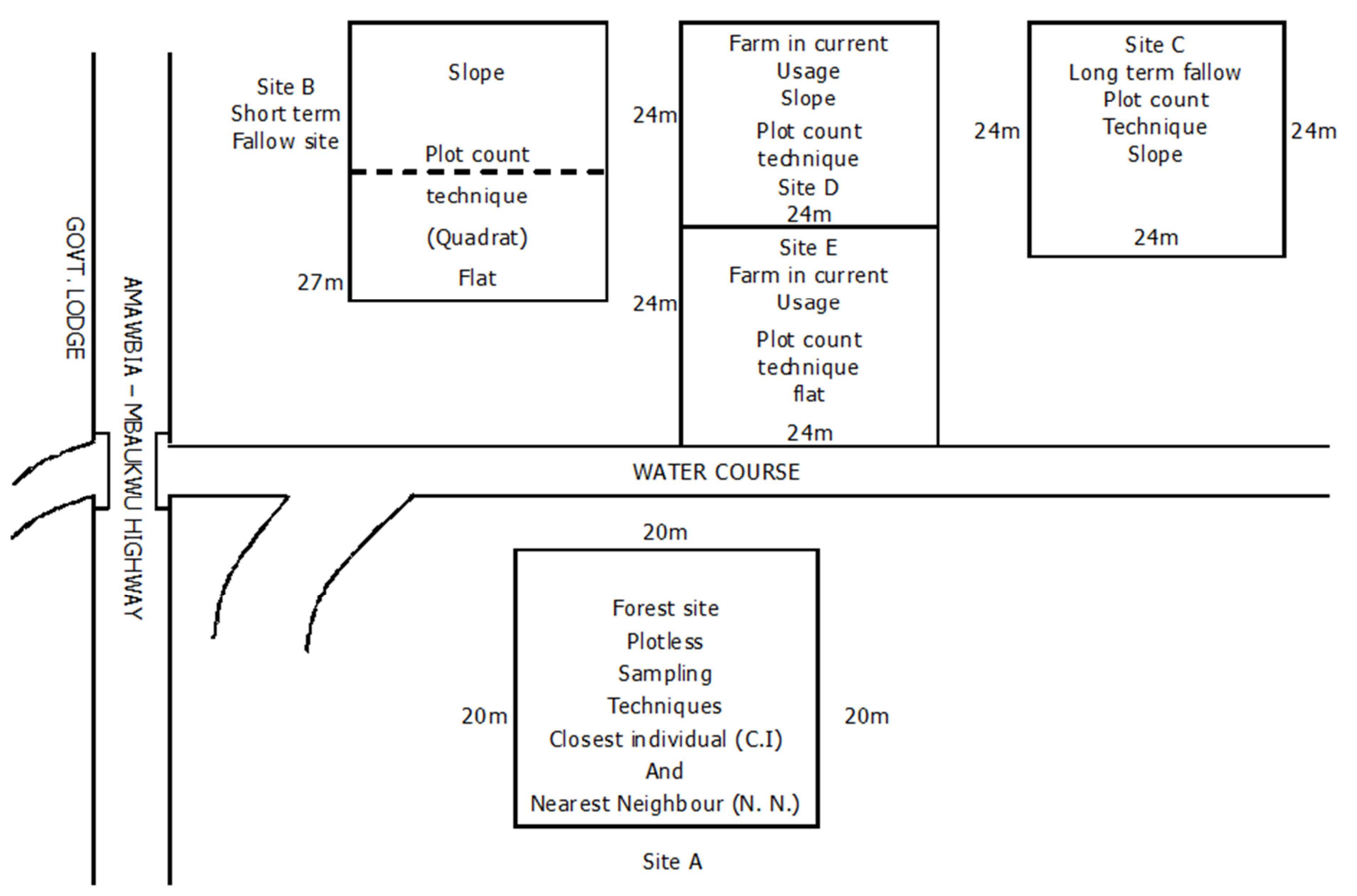

Figure 1. Study area showing sampling locations.

Closest Individual (C.I.) technique - a type of plotless sampling technique, was used for the forest site. Sampling points were marked with pegs. The closest (nearest) plant species to each sampling point were identified and their local and botanical names recorded. At each sampling point, two different measurements were taken. Firstly, the closest tree to each sampling point was identified and the distance between them measured and recorded. Finally, any tree whose stem was up to $1.3 \mathrm{~m}$ high, had the girth at breast height (gbh) measured immediately at that mark.

For the flat forested site (site A), plotless techniques were employed here. The species at the forest site were identified physically with the assistance of field taxonomists and some relevant texts ([1], [3] and [9]). The species and families were recorded. All individuals of each species were counted, their Gaith at breast height (Gbh) estimated and all these were recorded. The numbers of individual of each species were recorded for the rainy and dry season respectively. The number of individuals of each species were added up and used to estimate species composition and diversity.

For sites B, C, D and E, plot-count sampling technique was employed. Plot counts are usually carried out in herbaceous sites with known borders, lacking physical obstacles (as in sites filled with trees and other wooded vegetation). Firstly, the total plot size was ascertained. Next, the sampling intensity was worked out, determining $5 \%$ of the total plot size. Random sampling technique was selected because it does not create room for bias. Having determined the sample size (sampling intensity/sampling unit), two lines which represent two of the boundaries were used as coordinates on each plot. Prior to this, a set of random numbers were put together according to the number of times the quadrat will be placed. This set of random numbers were then used to estimate the exact points (locations) at which the quadrats will be placed. The random numbers were in pairs and wherever each corresponding pair intersect themselves, there the quadrat was placed, until the correct number of quadrats were placed. Quadrats used in all cases were $1 \mathrm{~m} \mathrm{x}$ $1 \mathrm{~m}(3.28 \mathrm{ft}) 2$ in size. They were placed thirty-six (36) times for site B and twenty-nine (29) times for the rest of the sites (C, D, and E). Each species in each quadrat was identified, counted and its numbers recorded. The entire exercise was repeated for each of the sites $\mathrm{C}, \mathrm{D}$. and $\mathrm{E}$, for both rainy and dry seasons.

\section{Results}

Species Composition and Growth Forms

Tables $1-5$ show the species composition (tree, climber, shrubs, grass and forb) of the five different land use sites. A total of 31 tree species, 18 shrubs species, 9 climbers, 37 grass and 97 forbs species distributed over 51 families were found in the sites. The forest site had most of the tree, shrub and climber species while the other sites had most of the forb and grass species (Table $2-5$ ). The forbs were so preponderant especially in the managed sites (fallow and current usage sites) that they were recorded as (forbs 'in families'). 
Table 1. Tree Species Composition of the Different Land Use Sites in Amawbia Watershed.

\begin{tabular}{|c|c|c|c|c|c|c|c|}
\hline $\mathbf{S} / \mathbf{N}$ & SPECIES & FAMILY & $\begin{array}{l}\text { FOREST } \\
\text { SITE }\end{array}$ & $\begin{array}{l}\text { SHORT } \\
\text { TERM } \\
\text { FALLOW } \\
\end{array}$ & $\begin{array}{l}\text { LONG TERM } \\
\text { FALLOW }\end{array}$ & $\begin{array}{l}\text { CURRENT USAGE } \\
\text { FARMING SLOPE }\end{array}$ & $\begin{array}{l}\text { CURRENT USAGE } \\
\text { FARMING FLAT }\end{array}$ \\
\hline 1 & Afzelia Africana & Caesalpiniaceae & $\sqrt{ }$ & $\mathrm{X}$ & $\mathrm{X}$ & $\mathrm{X}$ & $\mathrm{X}$ \\
\hline 2 & Albizia chaevelieri & Fabaceae & $\sqrt{ }$ & $\mathrm{X}$ & $\mathrm{X}$ & $\mathrm{X}$ & $\mathrm{X}$ \\
\hline 3 & Anthocleista djalonensis & Loganiaceae & $\sqrt{ }$ & $\mathrm{X}$ & $\mathrm{X}$ & $\mathrm{X}$ & $\mathrm{X}$ \\
\hline 4 & Barteria nigritiana & Ochnaceae & $\sqrt{ }$ & $\mathrm{X}$ & $\mathrm{X}$ & $\mathrm{X}$ & $\mathrm{X}$ \\
\hline 5 & Bridelia ferruginea & Euphorbiaceae & $\sqrt{ }$ & $\mathrm{X}$ & $\mathrm{X}$ & $X$ & $\mathrm{X}$ \\
\hline 6 & Citrus sinenses (seedlings) & Rutaceae & $\mathrm{X}$ & $\sqrt{ }$ & $\mathrm{X}$ & $\mathrm{X}$ & $\mathrm{X}$ \\
\hline 7 & Cocos nucifera (seedlings) & Arecaceae & $\mathrm{X}$ & $\sqrt{ }$ & $\mathrm{X}$ & $\mathrm{X}$ & $\mathrm{X}$ \\
\hline 8 & Dactyledenia barteri & Sterculiaceae & $\sqrt{ }$ & $\mathrm{X}$ & $\mathrm{X}$ & $\mathrm{X}$ & $\mathrm{X}$ \\
\hline 9 & Dialum guineense & Caesalpiniaceae & $\sqrt{ }$ & $\mathrm{X}$ & $\mathrm{X}$ & $\mathrm{X}$ & $\mathrm{X}$ \\
\hline 10 & Dichrostachys cinerea & Mimosoideae & $\sqrt{ }$ & $\mathrm{X}$ & $\mathrm{X}$ & $\mathrm{X}$ & $\mathrm{X}$ \\
\hline 11 & Elaeis guineensis & Arecaceae & $\sqrt{ }$ & $\sqrt{ }$ & $\mathrm{X}$ & $\mathrm{X}$ & $\mathrm{X}$ \\
\hline 12 & Erythrophleum suaveolens & Caesalpiniaceae & $\sqrt{ }$ & $\mathrm{X}$ & $\mathrm{X}$ & $\mathrm{X}$ & $\mathrm{X}$ \\
\hline 13 & Hevea braziliensis & Euphorbiaceae & $\sqrt{ }$ & $\mathrm{X}$ & $\mathrm{X}$ & $\mathrm{X}$ & $\mathrm{X}$ \\
\hline 14 & Holarrhena floribunda & Apocynaceae & $\sqrt{ }$ & $\mathrm{X}$ & $\mathrm{X}$ & $\mathrm{X}$ & $\mathrm{X}$ \\
\hline 15 & Klausinia anisata & Fabaceae & $\mathrm{X}$ & $\sqrt{ }$ & $\mathrm{X}$ & $X$ & $X$ \\
\hline 16 & $\begin{array}{l}\text { Mangifera indica } \\
\text { (seedlings) }\end{array}$ & Anacardiaceae & $\sqrt{ }$ & $\sqrt{ }$ & $X$ & $X$ & $X$ \\
\hline 17 & Milicia excelsa & Moraceae & $\sqrt{ }$ & $\mathrm{X}$ & $\mathrm{X}$ & $\mathrm{X}$ & $\mathrm{X}$ \\
\hline 18 & Napoleona imperialis & Lecithidaceae & $\sqrt{ }$ & $\mathrm{X}$ & $\mathrm{X}$ & $\mathrm{X}$ & $\mathrm{X}$ \\
\hline 19 & Nauclea latifolia & Rubiaceae & $\mathrm{X}$ & $X$ & $\sqrt{ }$ & $X$ & $X$ \\
\hline 20 & Newbouldia laevis & Bignoniaceae & $\sqrt{ }$ & $\mathrm{X}$ & $\mathrm{X}$ & $\mathrm{X}$ & $\mathrm{X}$ \\
\hline 21 & Peltoforum pterocarpus & Fabaceae & $\sqrt{ }$ & $\mathrm{X}$ & $\mathrm{X}$ & $\mathrm{X}$ & $\mathrm{X}$ \\
\hline 22 & Pentaclethra macrophyla & Mimosoideae & $\sqrt{ }$ & $\mathrm{X}$ & $\mathrm{X}$ & $\mathrm{X}$ & $\mathrm{X}$ \\
\hline 23 & $\begin{array}{l}\text { Psidium guajava } \\
\text { (seedlings) }\end{array}$ & Myrtaceae & $X$ & $\sqrt{ }$ & $X$ & $\mathrm{X}$ & $X$ \\
\hline 24 & Rothmania hispida & Rubiaceae & $\mathrm{X}$ & $\sqrt{ }$ & $\mathrm{X}$ & $\mathrm{X}$ & $\mathrm{X}$ \\
\hline 25 & Senna siamea & Caesalpiniaceae & $\sqrt{ }$ & $X$ & $\mathrm{X}$ & $X$ & $X$ \\
\hline 26 & Spondias mombin & Anacardiaceae & $\sqrt{ }$ & $\mathrm{X}$ & $\mathrm{X}$ & $\mathrm{X}$ & $\mathrm{X}$ \\
\hline 27 & Sporospaтит febrifugum & Bignoniaceae & $\sqrt{ }$ & $\mathrm{X}$ & $\mathrm{X}$ & $\mathrm{X}$ & $\mathrm{X}$ \\
\hline 28 & Sterculia tragacantha & Sterculiaceae & $\sqrt{ }$ & $\mathrm{X}$ & $\mathrm{X}$ & $\mathrm{X}$ & $\mathrm{X}$ \\
\hline 29 & Tetrapleura tetraptera & Mimosoideae & $\sqrt{ }$ & $\mathrm{X}$ & $\mathrm{X}$ & $\mathrm{X}$ & $\mathrm{X}$ \\
\hline 30 & Voacanga africana & Apocynaceae & $\sqrt{ }$ & $X$ & $\mathrm{X}$ & $X$ & $X$ \\
\hline \multirow[t]{2}{*}{31} & $\begin{array}{l}\text { Zanthaxylon } \\
\text { zanthaxyloides }\end{array}$ & Rutaceae & $\sqrt{ }$ & $X$ & $X$ & $X$ & $X$ \\
\hline & & & 25 & 7 & 1 & 0 & 0 \\
\hline
\end{tabular}

Table 2. Shrub Species Composition of the Different Land Use Sites in Amawbia Watershed.

\begin{tabular}{|c|c|c|c|c|c|c|c|}
\hline $\mathbf{S} / \mathbf{N}$ & SPECIES & FAMILY & $\begin{array}{l}\text { FOREST } \\
\text { SITE }\end{array}$ & $\begin{array}{l}\text { SHORT } \\
\text { TERM } \\
\text { FALLOW } \\
\end{array}$ & $\begin{array}{l}\text { LONG TERM } \\
\text { FALLOW }\end{array}$ & $\begin{array}{l}\text { CURRENT } \\
\text { USAGE } \\
\text { FARMING SLOPE }\end{array}$ & $\begin{array}{l}\text { CURRENT USAGE } \\
\text { FARMING FLAT }\end{array}$ \\
\hline 1 & Alchornea condifolia & Euphorbiaceae & $\sqrt{ }$ & $\mathrm{X}$ & $\mathrm{X}$ & $\mathrm{X}$ & $\mathrm{X}$ \\
\hline 2 & Ananas comosus & Bromeliaceae & $\sqrt{ }$ & $\sqrt{ }$ & $\mathrm{X}$ & $\mathrm{X}$ & $\mathrm{X}$ \\
\hline 3 & Annona senegalensis & Annonaceae & $\mathrm{X}$ & $\mathrm{X}$ & $\sqrt{ }$ & $\mathrm{X}$ & $\mathrm{X}$ \\
\hline 4 & Bambusa vulgaris & Poaceae & $\sqrt{ }$ & $\mathrm{X}$ & $\mathrm{X}$ & $\mathrm{X}$ & $\mathrm{X}$ \\
\hline 5 & Byrsocarpus coccineus & Connoraceae & $\sqrt{ }$ & $\mathrm{X}$ & $\mathrm{X}$ & $\mathrm{X}$ & $\mathrm{X}$ \\
\hline 6 & Cajanus cajans & Fabaceae & $\mathrm{X}$ & $\mathrm{X}$ & $\mathrm{X}$ & $\sqrt{ }$ & $\mathrm{X}$ \\
\hline 7 & Chromolaena odorata & Asteraceae & $\mathrm{X}$ & $\sqrt{ }$ & $\mathrm{X}$ & $\mathrm{X}$ & $\mathrm{X}$ \\
\hline 8 & Manihot esculentum & Euphorbiaceae & $\mathrm{X}$ & $\sqrt{ }$ & $\mathrm{X}$ & $\sqrt{ }$ & $\sqrt{ }$ \\
\hline 9 & Mimosa invisa & Mimosoideae & $\sqrt{ }$ & $\mathrm{X}$ & $\sqrt{ }$ & $\sqrt{ }$ & $\sqrt{ }$ \\
\hline 10 & Ocimum basilicum & Lamiaceae & $\mathrm{X}$ & $\mathrm{X}$ & $\mathrm{X}$ & $\mathrm{X}$ & $\sqrt{ }$ \\
\hline 11 & Olax viridis & Olacaceae & $\sqrt{ }$ & $\mathrm{X}$ & $\mathrm{X}$ & $\mathrm{X}$ & $\mathrm{X}$ \\
\hline 12 & Phaseolus vulgaris & Fabaceae & $\mathrm{X}$ & $\mathrm{X}$ & $\mathrm{X}$ & $\sqrt{ }$ & $\mathrm{X}$ \\
\hline 13 & Piliostigma thonningii & Caesalpiniaceae & $\mathrm{X}$ & $\mathrm{X}$ & $\sqrt{ }$ & $\sqrt{ }$ & $X$ \\
\hline 14 & Rauvolfia vomitoria & Apocynaceae & $\sqrt{ }$ & $\mathrm{X}$ & $\mathrm{X}$ & $\mathrm{X}$ & $\mathrm{X}$ \\
\hline 15 & $\begin{array}{l}\text { Sarcocephalum } \\
\text { laxiflora }\end{array}$ & Euphorbiaceae & $X$ & $\mathrm{X}$ & $\mathrm{X}$ & $\mathrm{X}$ & $\sqrt{ }$ \\
\hline 16 & Solanum melanguena & Solanaceae & $\mathrm{X}$ & $\mathrm{X}$ & $\mathrm{X}$ & $\mathrm{X}$ & $\sqrt{ }$ \\
\hline 17 & Uvaria chamae & Annonaceae & $X$ & $\mathrm{X}$ & $\sqrt{ }$ & $\mathrm{X}$ & $\mathrm{X}$ \\
\hline \multirow[t]{2}{*}{18} & Vernonia amygdalina & Asteraceae & $\mathrm{X}$ & $\mathrm{X}$ & $\mathrm{X}$ & $\sqrt{ }$ & $\sqrt{ }$ \\
\hline & & & 7 & 3 & 4 & 6 & 6 \\
\hline
\end{tabular}


Table 3. Climber Species Composition of the Different Land Use Sites in Amawbia Watershed.

\begin{tabular}{llllllll}
\hline \multirow{2}{*}{ S/N } & \multirow{2}{*}{ SPECIES } & FAMILY & FOREST SITE & $\begin{array}{l}\text { SHORT } \\
\text { TERM } \\
\text { FALLOW }\end{array}$ & $\begin{array}{l}\text { LONG } \\
\text { TERM } \\
\text { FALLOW }\end{array}$ & $\begin{array}{l}\text { CURRENT } \\
\text { USAGE } \\
\text { FARMING SLOPE }\end{array}$ & $\begin{array}{l}\text { CURRENT } \\
\text { USAGE } \\
\text { FARMING FLAT }\end{array}$ \\
\hline 1 & Cissus araliodes & Ampelidaceae & $\sqrt{ }$ & $\mathrm{X}$ & $\mathrm{X}$ & $\mathrm{X}$ & $\mathrm{X}$ \\
2 & Cucurbita pepo & Cucurbitaceae & $\mathrm{X}$ & $\mathrm{X}$ & $\mathrm{X}$ & $\sqrt{ }$ & $\sqrt{ }$ \\
3 & Desmodium scorpiurus & Fabaceae & $\mathrm{X}$ & $\mathrm{X}$ & $\sqrt{ }$ & $\mathrm{X}$ & $\mathrm{X}$ \\
4 & Dioscorea dumentorum & Dioscoreaceae & $\sqrt{ }$ & $\mathrm{X}$ & $\mathrm{X}$ & $\mathrm{X}$ & $\mathrm{X}$ \\
5 & Gongronema latifolium & Asclepiadaceae & $\sqrt{ }$ & $\mathrm{X}$ & $\mathrm{X}$ & $\mathrm{X}$ & $\mathrm{X}$ \\
6 & Mucuna pruriens & Fabaceae & $\sqrt{ }$ & $\mathrm{X}$ & $\mathrm{X}$ & $\mathrm{X}$ & $\mathrm{X}$ \\
7 & Peuraria phaseoloides & Fabaceae & $\sqrt{ }$ & $\mathrm{X}$ & $\mathrm{X}$ & $\mathrm{X}$ & $\mathrm{X}$ \\
8 & Smilax anceps & Smilaceae & $\sqrt{ }$ & $\mathrm{X}$ & $\mathrm{X}$ & $\mathrm{X}$ & $\mathrm{X}$ \\
9 & Telfeiria occidentalis & Cucurbitaceae & $\mathrm{X}$ & $\mathrm{X}$ & $\mathrm{X}$ & $\sqrt{ }$ & \\
& & & 6 & 0 & 1 & 2 & $\sqrt{ }$ \\
\hline
\end{tabular}

Table 4. Grass Species Composition of the Different Land Use Sites in Amawbia Watershed.

\begin{tabular}{|c|c|c|c|c|c|c|c|}
\hline $\mathbf{S} / \mathbf{N}$ & SPECIES & FAMILY & FOREST SITE & $\begin{array}{l}\text { SHORT } \\
\text { TERM } \\
\text { FALLOW }\end{array}$ & $\begin{array}{l}\text { LONG } \\
\text { TERM } \\
\text { FALLOW } \\
\end{array}$ & $\begin{array}{l}\text { CURRENT } \\
\text { USAGE } \\
\text { FARMING SLOPE }\end{array}$ & $\begin{array}{l}\text { CURRENT } \\
\text { USAGE } \\
\text { FARMING FLAT }\end{array}$ \\
\hline 1 & Acroceras zizanioides & Poacea & $\mathrm{X}$ & $\sqrt{ }$ & $\mathrm{x}$ & $\mathrm{X}$ & $\mathrm{X}$ \\
\hline 2 & Andropogon gayanus & Poacea & $\mathrm{X}$ & $\sqrt{ }$ & $\sqrt{ }$ & $\mathrm{X}$ & $\mathrm{X}$ \\
\hline 3 & Andropogon tectorum & Poacea & $\mathrm{X}$ & $\sqrt{ }$ & $\sqrt{ }$ & $\mathrm{x}$ & $\mathrm{X}$ \\
\hline 4 & Axonopus compressus & Poacea & $\mathrm{X}$ & $\mathrm{X}$ & $\mathrm{X}$ & $\mathrm{X}$ & $\mathrm{X}$ \\
\hline 5 & Brachiara deflexa & Poacea & $\mathrm{X}$ & $\mathrm{X}$ & $\mathrm{X}$ & $\mathrm{X}$ & $\mathrm{X}$ \\
\hline 6 & Brachiara lata & Poacea & $\mathrm{X}$ & $\sqrt{ }$ & $\mathrm{X}$ & $\mathrm{X}$ & $\mathrm{X}$ \\
\hline 7 & Chloris pilosa & Poacea & $\mathrm{X}$ & $\mathrm{X}$ & $\mathrm{X}$ & $\mathrm{X}$ & $\mathrm{X}$ \\
\hline 8 & Cymbopogon cittratus & Poacea & $\mathrm{X}$ & $\sqrt{ }$ & $\mathrm{X}$ & $\sqrt{ }$ & $\sqrt{ }$ \\
\hline 9 & Cymbopogon giganteus & Poacea & $\mathrm{X}$ & $\sqrt{ }$ & $\sqrt{ }$ & $\mathrm{X}$ & $\mathrm{X}$ \\
\hline 10 & Cynodon dactylon & Poacea & $\mathrm{X}$ & $\sqrt{ }$ & $\mathrm{X}$ & $\mathrm{X}$ & $\mathrm{X}$ \\
\hline 11 & Digitaria gayana & Poacea & $\mathrm{X}$ & $\sqrt{ }$ & $\mathrm{X}$ & $\mathrm{X}$ & $\mathrm{X}$ \\
\hline 12 & Digitaria horizontalis & Poacea & $\mathrm{X}$ & $\sqrt{ }$ & $\mathrm{X}$ & $\mathrm{X}$ & $\mathrm{X}$ \\
\hline 13 & Digitaria nuda & Poacea & $\mathrm{X}$ & $\mathrm{X}$ & $\mathrm{X}$ & $\mathrm{X}$ & $\mathrm{X}$ \\
\hline 14 & Echinochloa colona & Poacea & $\mathrm{X}$ & $\mathrm{X}$ & $\mathrm{X}$ & $\mathrm{X}$ & $\mathrm{X}$ \\
\hline 15 & Echinochloa obtusiflora & Poacea & $\mathrm{X}$ & $\mathrm{X}$ & $\mathrm{X}$ & $\mathrm{X}$ & $\mathrm{X}$ \\
\hline 16 & Eleusine indica & Poacea & $\mathrm{X}$ & $\mathrm{X}$ & $\mathrm{x}$ & $\mathrm{X}$ & $\mathrm{X}$ \\
\hline 17 & Eragrostis atrovirens & Poacea & $\mathrm{X}$ & $\sqrt{ }$ & $\mathrm{X}$ & $\mathrm{X}$ & $\mathrm{X}$ \\
\hline 18 & Fragrostis tremula & Poacea & $\mathrm{X}$ & $\mathrm{X}$ & $\mathrm{X}$ & $\mathrm{x}$ & $\mathrm{X}$ \\
\hline 19 & Hackelochloa granularis & Poacea & $\mathrm{X}$ & $\sqrt{ }$ & $\sqrt{ }$ & $\sqrt{ }$ & $\sqrt{ }$ \\
\hline 20 & Imperata cylindrica & Poacea & $\sqrt{ }$ & $\sqrt{ }$ & $\sqrt{ }$ & $\sqrt{ }$ & $\sqrt{ }$ \\
\hline 21 & Leersia hexandra & Poacea & $\mathrm{X}$ & $\mathrm{X}$ & $\mathrm{X}$ & $\mathrm{X}$ & $\mathrm{x}$ \\
\hline 22 & Oryza sativa & Poacea & $\mathrm{X}$ & $\mathrm{X}$ & $\mathrm{X}$ & $\sqrt{ }$ & $\sqrt{ }$ \\
\hline 23 & Panicum laxum & Poacea & $\mathrm{X}$ & $\sqrt{ }$ & $\mathrm{X}$ & $\mathrm{X}$ & $\mathrm{X}$ \\
\hline 24 & Panicum maximum & Poacea & $\sqrt{ }$ & $\sqrt{ }$ & $\sqrt{ }$ & $\sqrt{ }$ & $\sqrt{ }$ \\
\hline 25 & Panicum repens & Poacea & $\mathrm{X}$ & $\mathrm{X}$ & $\mathrm{X}$ & $\mathrm{X}$ & $\mathrm{X}$ \\
\hline 26 & Pennisetum pedicellatum & Poacea & $\mathrm{X}$ & $\mathrm{X}$ & $\sqrt{ }$ & $\mathrm{X}$ & $\mathrm{X}$ \\
\hline 27 & Pennisetum polystachion & Poacea & $\mathrm{X}$ & $\mathrm{X}$ & $\sqrt{ }$ & $\mathrm{X}$ & $\mathrm{X}$ \\
\hline 28 & Paspalum conjugatum & Poacea & $\mathrm{X}$ & $\sqrt{ }$ & $\mathrm{X}$ & $\mathrm{X}$ & $\mathrm{X}$ \\
\hline 29 & Paspalum scrobiculatum & Poacea & $\mathrm{X}$ & $\sqrt{ }$ & $\mathrm{X}$ & $\sqrt{ }$ & $\sqrt{ }$ \\
\hline 30 & Rhynchelytrum repens & Poacea & $\mathrm{X}$ & $\sqrt{ }$ & $\mathrm{X}$ & $\mathrm{x}$ & $\mathrm{X}$ \\
\hline 31 & $\begin{array}{l}\text { Rottboelia } \\
\text { cochinchinensis }\end{array}$ & Poacea & $\mathrm{X}$ & $\sqrt{ }$ & $\sqrt{ }$ & $\mathrm{X}$ & $\mathrm{X}$ \\
\hline 32 & Saccharum officinarum & Poacea & $\mathrm{X}$ & $\mathrm{X}$ & $\mathrm{X}$ & $\mathrm{X}$ & $\mathrm{X}$ \\
\hline 33 & Setaria barbata & Poacea & $\mathrm{X}$ & $\sqrt{ }$ & $\mathrm{X}$ & $\mathrm{X}$ & $\mathrm{X}$ \\
\hline 34 & Setaria longiseta & poacea & $\mathrm{X}$ & $\sqrt{ }$ & $\mathrm{X}$ & $\mathrm{X}$ & $\mathrm{X}$ \\
\hline 35 & Sorghum arundinaceum & Poacea & $\mathrm{X}$ & $\sqrt{ }$ & $\sqrt{ }$ & $\sqrt{ }$ & $\sqrt{ }$ \\
\hline 36 & Sporobolus pyramidalis & Poacea & $\mathrm{X}$ & $\sqrt{ }$ & $\mathrm{X}$ & $\mathrm{X}$ & $\mathrm{X}$ \\
\hline \multirow[t]{2}{*}{37} & Zea mays & Poacea & $\mathrm{X}$ & $\sqrt{ }$ & $\mathrm{X}$ & $\sqrt{ }$ & $\sqrt{ }$ \\
\hline & & & 2 & 23 & 10 & 8 & 8 \\
\hline
\end{tabular}


Table 5. Forb Species Composition of the Different Land Use Sites in Amawbia Watershed.

\begin{tabular}{|c|c|c|c|c|c|c|c|}
\hline $\mathbf{S} / \mathbf{N}$ & $\begin{array}{l}\text { NO OF } \\
\text { SPECIES }\end{array}$ & FAMILY & $\begin{array}{l}\text { FOREST } \\
\text { SITE }\end{array}$ & $\begin{array}{l}\text { SHORT TERM } \\
\text { FALLOW }\end{array}$ & $\begin{array}{l}\text { LONG TERM } \\
\text { FALLOW }\end{array}$ & $\begin{array}{l}\text { CURRENT } \\
\text { USAGE } \\
\text { FARMING SLOPE }\end{array}$ & $\begin{array}{l}\text { CURRENT } \\
\text { USAGE } \\
\text { FARMING FLAT }\end{array}$ \\
\hline 1 & 3 & Acanthaceae & $\mathrm{X}$ & $\sqrt{ }$ & $\sqrt{ }$ & $\sqrt{ }$ & $\sqrt{ }$ \\
\hline 2 & 10 & Amaranthaceae & $\mathrm{X}$ & $\sqrt{ }$ & $\sqrt{ }$ & $\sqrt{ }$ & $\sqrt{ }$ \\
\hline 3 & 10 & Asteraceae & $\mathrm{X}$ & $\sqrt{ }$ & $\sqrt{ }$ & $\sqrt{ }$ & $\sqrt{ }$ \\
\hline 4 & 2 & Capparidaceae & $\mathrm{X}$ & $\sqrt{ }$ & $\sqrt{ }$ & $\sqrt{ }$ & $\sqrt{ }$ \\
\hline 5 & 2 & Commelinaceae & $\mathrm{X}$ & $\sqrt{ }$ & $\sqrt{ }$ & $\sqrt{ }$ & $\sqrt{ }$ \\
\hline 6 & 5 & Convolvulaceae & $\mathrm{X}$ & $\sqrt{ }$ & $\sqrt{ }$ & $\sqrt{ }$ & $\sqrt{ }$ \\
\hline 7 & 13 & Cyperaceae & $\mathrm{X}$ & $\sqrt{ }$ & $\sqrt{ }$ & $\sqrt{ }$ & $\sqrt{ }$ \\
\hline 8 & 6 & Euphorbiaceae & $\mathrm{X}$ & $\sqrt{ }$ & $\sqrt{ }$ & $\sqrt{ }$ & $\sqrt{ }$ \\
\hline 9 & 01 & Rutaceae & $\mathrm{X}$ & $\mathrm{X}$ & $\mathrm{X}$ & $\sqrt{ }$ & $\sqrt{ }$ \\
\hline 10 & 4 & Lamiaceae & $\mathrm{X}$ & $\sqrt{ }$ & $\sqrt{ }$ & $\sqrt{ }$ & $\sqrt{ }$ \\
\hline 11 & 5 & Malvaceae & $\mathrm{X}$ & $\sqrt{ }$ & $\sqrt{ }$ & $\sqrt{ }$ & $\sqrt{ }$ \\
\hline 12 & 2 & Melastomataceae & $\mathrm{X}$ & $\sqrt{ }$ & $\sqrt{ }$ & $\sqrt{ }$ & $\sqrt{ }$ \\
\hline 13 & 3 & Onagraceae & $\mathrm{X}$ & $\sqrt{ }$ & $\sqrt{ }$ & $\sqrt{ }$ & $\sqrt{ }$ \\
\hline 14 & 7 & Rubiaceae & $\mathrm{X}$ & $\sqrt{ }$ & $\sqrt{ }$ & $\sqrt{ }$ & $\sqrt{ }$ \\
\hline 15 & 01 & Sphenocleaceae & $\mathrm{X}$ & $\sqrt{ }$ & $\sqrt{ }$ & $\sqrt{ }$ & $\sqrt{ }$ \\
\hline 16 & 2 & Stercliaceae & $\mathrm{X}$ & $\sqrt{ }$ & $\sqrt{ }$ & $\sqrt{ }$ & $\sqrt{ }$ \\
\hline 17 & 2 & Fabaceae & $\mathrm{X}$ & $\sqrt{ }$ & $\sqrt{ }$ & $\sqrt{ }$ & $\sqrt{ }$ \\
\hline 18 & 3 & Nyctaginaceae & $\mathrm{X}$ & $\sqrt{ }$ & $\sqrt{ }$ & $\sqrt{ }$ & $\sqrt{ }$ \\
\hline 19 & 01 & Polygonaceae & $\mathrm{X}$ & $\sqrt{ }$ & $\sqrt{ }$ & $\sqrt{ }$ & $\sqrt{ }$ \\
\hline 20 & 01 & Pontederaceae & $\mathrm{X}$ & $\sqrt{ }$ & $\sqrt{ }$ & $\sqrt{ }$ & $\sqrt{ }$ \\
\hline 21 & 01 & Loganiaceae & $\mathrm{X}$ & $\sqrt{ }$ & $\sqrt{ }$ & $\sqrt{ }$ & $\sqrt{ }$ \\
\hline 22 & 2 & Musaceae & $\mathrm{X}$ & $\sqrt{ }$ & $\sqrt{ }$ & $\sqrt{ }$ & $\sqrt{ }$ \\
\hline 23 & 01 & Piperaceae & $\mathrm{X}$ & $\sqrt{ }$ & $\sqrt{ }$ & $\sqrt{ }$ & $\sqrt{ }$ \\
\hline 24 & 01 & Mimosaoideae & $\mathrm{X}$ & $\sqrt{ }$ & $\sqrt{ }$ & $\sqrt{ }$ & $\sqrt{ }$ \\
\hline 25 & 01 & Solanaceae & $\mathrm{X}$ & $\sqrt{ }$ & $\sqrt{ }$ & $\sqrt{ }$ & $\sqrt{ }$ \\
\hline 26 & 01 & Verbenaceae & $\mathrm{X}$ & $\sqrt{ }$ & $\sqrt{ }$ & $\sqrt{ }$ & $\sqrt{ }$ \\
\hline 27 & 2 & Portulacaceae & $\mathrm{X}$ & $\sqrt{ }$ & $\sqrt{ }$ & $\sqrt{ }$ & $\sqrt{ }$ \\
\hline 28 & 01 & Pedaliaceae & $\mathrm{X}$ & $\sqrt{ }$ & $\sqrt{ }$ & $\sqrt{ }$ & $\sqrt{ }$ \\
\hline 29 & 02 & Urticaceae & $\mathrm{X}$ & $\sqrt{ }$ & $\sqrt{ }$ & $\sqrt{ }$ & $\sqrt{ }$ \\
\hline 30 & 01 & Hydrophyllaceae & $\mathrm{X}$ & $\sqrt{ }$ & $\sqrt{ }$ & $\sqrt{ }$ & $\sqrt{ }$ \\
\hline \multirow[t]{2}{*}{31} & 01 & Tiliaceae & $\mathrm{X}$ & $\sqrt{ }$ & $\sqrt{ }$ & $\sqrt{ }$ & $\sqrt{ }$ \\
\hline & & & 0 & $59(23)$ & $58(18)$ & $61(24)$ & $61(24)$ \\
\hline
\end{tabular}

\section{Conclusion}

Originally the Amawbia watershed was densely forested. This denoted a very rich species composition. Presently the watershed has been degraded by overwhelming anthropogenic influences. This has resulted in very poor biodiversity (only 189 plant species and very sparse Animal populations). 31 tree, 18 shrubs, 9 climbers, 37 grass and 97 forbs, species. There is need for government to protect the watershed from negative influences and to introduce more useful species to further enrich the species richness and diversity.

\section{References}

[1] Akobundu, I. O. and Agyakwa, C. W. (1998). A handbook of West African Weeds (2nd ed). Nigeria: International Institute of Tropical Agriculture, 564pp.

[2] Conservation Technology Information Center (2009). What is a watershed? West Lafayette, Indiana, USA. 1p.

[3] Gill, L. S. (1988). Taxonomy of flowering plants. Nigeria: Africana-Fep publishers, pp. 123-288.
[4] Idodo-Umeh (2011). College Biology. Idodo Umeh publishers limited. Nigeria. $657 \mathrm{pp}$.

[5] Ingwu, A. (2006). Development in Nigeria. Who should govern our watershed: A case study from northern Cross River State, Nigeria. Retrieved February $4^{\text {th }}, 2006$.

http://www.cenrce.org/eng/projects/ace/agnes/presentation.pdf

[6] Ministry of Agriculture, Awka (2009). Mean Monthly climatological data (handbill). Anambra State. Nigeria. 2pp.

[7] Mywatershedwatch.org (2016). Why are watersheds Important. USA. 866pp.

[8] New World Encyclopedia (2009). Watershed/Drainage basins. http://www.newworldencyclopedia.org/entry/watershed. U.S.A. Accessed, March 2011. 2pp.

[9] Nyananyo, B. L. (2006) Plants from the Niger Delta. Nigeria: Onyoma Research Publications, 403pp.

[10] The Nature Conservancy (2016). Watersheds USA. 101pp.

[11] United States Geological Survey (2000). Important Watershed Characteristics. http://www.egr.msu.edu/northco2/BE481/Wshed char.htm. 